体育学研究第 50 巻記念特集：体育科教育学

\title{
体育学研究における体育科教育学研究の成果と課題
}

\author{
高橋 健夫 岡出 美則 長谷川悦示
}

\section{Result and tasks in research in pedaogogy of physical education in Japan Journal of Physical Education, Health and Sport Sciences}

Takeo Takahashi, Yoshinori Okade and Etushi Hasegawa

\section{Key words : Curriculum Research, Instruction Research, Basic Study for Physical Edu- cation}

(Japan J. Phys. Educ. Hlth. Sport Sci. 50: 359-368, May, 2005)

キーワード：カリキュラム研究，授業研究，授業 の基礎研究

序

日本では，体育授業を対象とした学問を体育科 教育学と呼んでいる。これに対し，体育授業に限 定されているわけではないが，ドイツ語圏では類 似の研究領域をスポーツ教育学 (Sport pädagogik), 英語圈では体育教育学（pedagogy of physical education）と呼んでいる。この領域 が体育学 (スポーツ科学) の専門科学分野として 成立したのは 70 年代になってからのことである が，その後国際的に急速な発展をみせ，80年代 になるとSiedentop（1983）が，「この專門科学 がスポーツ科学の中の嫡子として承認された」と 宣言するにいたる。一方わが国の（社）体育学会 に体育科教育学専門分科会が位置づいたのは 1978 年のことであったが, 同様に急成長を遂げ, 2005 年 1 月現在の会員数は 760 人にのぼり, 学会 大会での発表題数は各専門分科会の中で 1,2 を
競うほどになっている.

体育科教育学の研究領域は, 発表登録コードに 従えば, (1)体育科教育原論, (2)教育課程論, (3)学 習者論, (4)教材論 (学習内容論), (5)方法論, (6) 評価論，(7)体育科教育に関わる制度や政策，その 基礎となるイデオロギーの研究, 8)体育教師に望 まれる知識, 技能, 倫理規範, パーソナリティー の研究に区分されている. しかし, 英語圈では, カリキュラム研究, 学習指導研究, 教師教育研究 が主たる研究対象になっており,ドイツ語圈では, これらの他に教科の存在根拠の検討や科学論が位 置づけられている（岡出，2001）。わが国ではこ の専門分科学の位置づけや研究領域を論じた著書 (成田ほか, 1987 ; 竹田ほか, 1997) は著されて いても, 体育学研究には前川（1974）の総説論文 以外にはみられない。

前川は，これまでの体育科教育法には(1)体育教 育に関する研究が実践と乘離していること，(2)授 業研究が盛んに行われているにもかかわらず，そ の成果が蓄積されるシステムが存在していないこ と, (3)学習指導要領作成の根拠となる長期的研究
筑波大学大学院人間総合科学研究科

干 305-8574 つくば市天王台 1-1-1

連絡先 高橋健夫
Cooperative Graduate Programs, University of Tsukuba 1-1-1 Tennodai, Tsukubashi, Ibaraki, 305-8574

Correspondingauthor takeo@taiiku.tsukuba.ac.jp 
が欠如しているなどの問題があったとし，体育関 係諸科学の成果をふまえて，体育という教育学的 な営みを一層推進する体育科教育学の必要性を訴 えた。またこの専門分科学では(1)カリキュラム研 究, (2)学習指導研究, (3)評価研究が中心的な研究 課題になると指摘した.

一方，高橋（1987）は，国際的なスポーツ教育 学研究の動向を分析し, 特に研究方法に着目して, 体育科教育学の研究領域を(1)体育の授業研究（実 証的研究)，(2)体育の授業づくり研究（カリキュ ラム論, 方法論等の理論的研究), (3)体育授業の 基礎的研究（他の専門科学的方法による研究，評 価法の研究, 学問論) の3 領域に整理した.

まだオーソライズされた研究領域が確定してい るわけではないが，これまでの体育学研究に揭載 された論文は高橋が指摘した 3 領域の中に収ま る.そこで以下ではその分類にしたがい，これま で掲載された論文の成果を，(1)カリキュラム研究 (授業づくり研究)，(2)授業研究，(3)授業の基礎的 研究の 3 点から概観し, 今後の研究課題について 考察したい。

\section{I カリキュラム研究の成果}

カリキュラム論は, 体育科教育学の主要な研究 テーマであり，特に，教科としての存在基盤を社 会的に示すうえでは重要になる，そのため，北米 やドイツ語圈では，多様な教科論が提案されてき た.しかし，残念なことにわが国の体育学研究に はこのテーマに関する論文はあまりみられず，多 くは外国の研究者や研究団体の理論を中心に論議 を行っている。

例えば岡出（1983）は，Grupeの理論を通して 運動学習の必要性やその教育的意義を論じ，人間 の身体は「身体保有」と「身体存在」という両義 的関係をもつこと，そしてこの両義的関係の中で 自分自身や他人，さらには世界を知っていくので あり，その媒体が運動であると指摘した。また， その連動自体が文化的拘束との緊張関係の中で生 み出されていることにも注目している。朝岡 （1994）の論もこの延長線上に位置づく．彼は，
身体知の獲得をめざす広義の運動学習では自分自 身の身体の対象化のみではなく，他者の身体への 「同一感」や「対一感」といった人間に根源的な 認識能力獲得が可能になると指摘し，それをもっ て教科の必要性の根拠としている。これに対し中 村（2003）は，体育教師が評価の観点，方法を可 能な限り説明すべきだと指摘した上で，スポーツ 文化創造への着想を学習者に育んでいくべきだと 主張した。

この他，1980年代後半になるとドイッ，アメ リカ，ソビエト，イギリスのカリキュラム改革の 動向が報告されるようになる，例えば竹田ほか （1985）は，旧西ドイツにおけるスポーツギムナ ジウムがミュンヘンオリンピック招致決定と東ド イツに対抗する競技選手盖成の制度的方策の確立 という動きを背景に開設されたが，それはギムナ ジウムの教育改革促進という側面も備えていたと 指摘した。このような動きは, 学校内のスポーツ を学校外のスポーツの単なる再生の場ではなく, その批判的創造の場として位置づくとの認識を生 み出していく，岡出（1997）は，このような状況 の中で，スポーツが備えている達成，共同，自分 の世界と環境，世界の経験，表現，健康，プレイ という複数の意味が教育学的視点から提案されて いったと分析している．また近藤（1997）は，近 年には身体を中核にしたスポーツ教育実践が構想 されるようになり，スポーツをする人間やスポー ツそれ自体の変容可能性に目が向けられるように なったと指摘している.

ソビエトでは体力検定制度が完成し，その合格 が教師に義務づけられて以降，テスト制度が授業 を方向づける現象が生み出されたが，そのような 体力テストの準備時間と化した体育授業は生徒に 魅力を欠き，教員の人材確保も困難になっていっ た.このような体育実践に対する批判が学校体育 改革の一契機となり，国民の心身の調和のとれた 発達という観点から体育の授業時数が増加するこ とになったと指摘されている（里見，1992）。

カリキュラム改革の動きはアメリカにも顕著に 現れる.アメリカの教育改革に伴う概念学習の提 案や, 健康・体力問題と連動しながら提案されて 
きた「体力づくり」から新たな「フィットネス教 育」への転換の動きがあった。そこでは例えば, Brunerの構造化論に依拠しながら，自己教育力 の育成に「概念学習」が有効であるとの認識が広 まっているという. また,このような概念学習は, 健康 - 体力問題との関わりの中で, 運動の価值認 識, 運動・スポーツについての基本的概念, そし て自己教育力の育成に対して効果的な方法として 発展していくことが予想される，と指摘されてい る(井谷, 1993，2001）。

しかし，このような制度改変をめざす動きが， 実際の授業変革に結びつくには時間がかかること も指摘されている．例えばイギリスでは，ナショ ナルカリキュラム導入が学校内で体育の必要性を 主張する根拠となっているが，その拘束力を受け ない私学では, 従来と大差のない授業が展開され ているという（鈴木，2000）。

このような外国の状況に比して，わが国のカリ キュラム研究は, 歴史研究の範疇にとどまってい る，例えば草深（1996）は，教育使節団報告書の 作成過程の分析を通し，そこには勝利至上主義を 排しつつ，体育・スポーツの住民自治による発展 をめざし，その核として学校を位置づけることで 日本民主主義の担い手を育成しようとする構想が みられたと指摘している。

\section{II 体育の授業研究}

\section{1. 教師の指導行動の研究}

体育授業中の効果的な教師行動を明らかにしよ うとする研究が進められてきた. 佐藤ほか (1978) は, 高等学校教員養成課程の学生を対象に, 4 週 間の教育実習期間中の指導技術や指導観の変容を 検討している. その結果, (1)実習生の指導技術に は階層的秩序にしたがって発達すること，(2)この 発達水準をふまえることによって実習技術の指導 が客観的に評価できること，(3)実習生の自主的討 議を推進することによって，指導観や授業認識の 発展性が裏付けられることなどを見いだしてい る.

高橋らは，組織的観察法を用い，体育授業中の
教師行動に関する一連の研究を発表している。ま ず，授業中の教師行動の全体構造を 3 秒単位でイ ベント記録し, 直接的指導, マネジメント, 巡視, 相互作用の 4 つ行動で構成されること, それぞ れの行動が $20 \%$ から $30 \%$ あることを明らかに している.また，それぞれの行動は授業において 重要な意義をもつが，それらの行動頻度と子ども による形成的授業評価との関係から, 直接的指導 やマネージメントは授業評価とマイナスの関係を 示し, 相互作用（励まし, 肯定的・矯正的フィー ドバック）のみがプラスに関係することを明らか にしている（高橋ほか，1991）。さらに高橋ほか （1989）はCAFIAS 観察法を応用して, 教師行動 と学習者行動 (ALT-PE) 及び形成的授業評価と の関係について分析し，相互作用行動の頻度と ALT-PEや形成的授業評価とがプラスに関係する ことを見いだしている。

これらの研究を受けて深見ほか (2000) は, 単 元レベルで研究を進め (6 単元, 6教師), 単元過 程における教師のフィードバック行動の推移と, それが学習成果に与える影響を明らかにした。す なわち，(1)成功裡な単元（4単元）では, 形成的 授業評価が授業時間の推移とともに向上する。(2) 直接的指導場面やマネジメント場面の時間量は漸 減, 逆に運動学習場面が漸增する. その結果(3)教 師の相互作用行動は增加する. しかしながら, 授

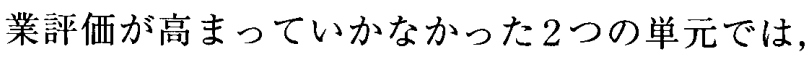
そのような推移のパターンは見られなかったと指 摘している.また深見ほか（1997）は，フィード バック行動の量と質（双向性, 伝達性, 共感性, 技術性, 表現内容) と児童の受け止め方（助言の 有無, 助言の有効性) の関係を分析し, フィード バックの質が, 児童の受け止め方や形成的授業評 価により強く関係することを明らかにしている。

伊藤ほか（2002）は，ダンス授業における教師 行動を組織的観察法によって記述し, 生徒の授業 評価（ダンス授業評価法）との関係から望ましい 教師行動を導き出そうとした。その結果, (1)教師 の運動参加は生徒の授業評価にプラスに影響する こと，(2)認知面に関わる矯正的フィードバックが 有効であること, (3)小集団を対象とする教師の働 
きかけが効果的であること等が明らかであったと 報告している。

上原ほか $(2000 ， 2003)$ は，7名の教師が担当 する体育授業における教師の言語的相互作用にお ける使用品詞を分析している，そこでは態度得点 を顕著に高めた学級とそうでない学級を教師の逐 語記録にもとづいて比較検討した。その結果，授 業全体では副詞 (叙述), 副詞 (語の副詞), 形容 詞（二項対立）の3つの品詞において上位群の使 用頻度が多かったとし，その原因として教師の実 践的見識に関わる知識の関与を指摘している.

\section{2. 学習者行動の研究}

授業中の学習者行動に焦点を当てた研究も活発 に行われてきた．まず高橋ほか（1989）は，国際 的にALT-PE観察法による研究が注目されてい ることから，この観察法の有効性を览童の形成的 授業評価との関係を分析することにより検証しよ うとした。 その結果, 成功裡な学習従事 (ALTPE）は授業時間全体の $30 \%$ ，運動学習従事は $10 \%$ ，主運動は 7一8\%になってしまうことが明 らかにされた，そのような傾向は，アメリカやカ ナダの研究とほぼ一致した。また，運動学習場面 や学習従事，ALT，運動の ALT と形成的授業評 価とは有意にプラスの関係を示した。このことか ら，ALT-PE観察法は学習成果を知るための有効 な観察法であると判断された。

しかし，ALT-PE 観察法は複雑で多くの観察者 が必要になることから，福ヶ迫ほか（2003）は一 人で観察できるGTS法を適用して，運動学習場 面の時間量やそこでの学習従事量（学習密度）を 観察する方法を開発するとともに，それらが形成 的授業評価に及ほす影響について分析した。その 結果, 運動学習場面の時間量や学習従事（特に運 動学習従事) 量が授業評価とプラスに関係し，マ ネジメント場面やオフタスク行動がマイナスに関 係すること，また，その関係の強さはALT-PE のそれ以上に強くなることを明らかにした。

この研究に連動して, 米村ほか（2004）は, 福ヶ迫らの行った研究デー夕を適用して, 運動学 習場面での「学習の䨌囲気（人間関係行動と情意
的行動)」を観察するとともに，それらの行動と 形成的授業評価との関係について分析した。その 結果，肯定的な人間関係行動や肯定的情意行動は 授業評価とプラスに関係し，逆に否定的人間関係 や否定的人間関係行動は授業評価にマイナスに影 響することが明らかであった。さらに米村ほか （2004）は，このような授業過程の「学習の勢い」 や「学習の雲囲気」に関わる行動的特徵が览童の 形成的授業評価をどの程度規定するかを重回帰分 析によって検討した。そして，60授業全体を対 象として分析した結果，「学習の勢い」に関わる 2 要因（学習従事，オフタスク）と「学習の䨌囲 気」に関わる 4 要因（肯定的・否定的人間関係及 び肯定的・否定的情意行動）が形成的授業評価に 対して，75\%という大きな規定力をもつことを 明らかにした。

\section{3. 体力や運動能力に焦点をあてた授業研究}

体力や各種スポーツの運動能力の向上を目的と した授業研究も多数見られる．長沢ほか（1975） は，教科体育の「健康の増進と体力の向上」に果 たす役割を検証するために，基礎的な運動教材に 要する運動量を検討している，運動教材中の運動 量は実験室で測定されると同時に実際の授業の夕 イムスタディー法 (期間記録) による推測值から 測られたが，健康の増進と体力の向上の視点から みると，体育授業での主要運動は，時間的にも質 的にも不十分なものと結論づけ，適正な運動量の 確保のためにはエネルギー消費の高い教材を配分 したり，施設・用具を拡充したり，指導形態の改 善を図る必要があると指摘した。また，原田ほか （1986）は，運動強度に対する览童の感覚（RPE） を推定した教師の主観運動強度（SIP）が授業で 有効な運動量調整の方法になるかどうかを検討 し，それが運動量調整に有効に機能すると報告し ている.

投能力の向上に注目した研究もいくつかみられ る. 金ほか（1988）は韓国の幼览と小学生を対象 に, 走 $(25 \mathrm{~m}$ 走), 跳 (立ち幅跳び), 投（テニ スボール遠投）の基礎的運動技能の変容を量的・ 質的観点から検討し，男女双方の走，跳の運動技 
能に直線的な発達傾向を見いだしている.しかし， 投では男には直線的な発達傾向がみられたが，女 子ではそれほど顕著な発達傾向がみなれないと報 告した。一方，尾縣ほか（2001）は小学生を対象 にオーバーハンドスロー能力を改善するために有 効で興味を喚起する学習プログラムを開発し，そ の効果を検証している。 そこでは，(1)男女とも遠 投距離が有意に向上したこと，(2)男子において遠 投能力水準が低い者ほど大きな向上が認められた こと，(3)男子は投射初速度の増加が向上に強く影 響したこと，(4)脚の準備動作や主動作中の体幹動 作に習熟が認められたことなどを報告している. 高本ほか（2004） も対象学年を変えて同様の研究 を行い, 学年段階での遠投距離や投の形態の発達 様相を比較検討している。

陸上競技（運動）教材を対象とした研究として， 堀ら（2003）は，高校生男子生徒を持久走 $(3000 \mathrm{~m})$ の記録をもとに均等な 3 群に分け，「一 定距離を制限時間内に全力で走る全力走」，「運動 時間をほぼ同じにする内回り法」，「同一のPER 尺度で走る方法」の 3 つの指導法で 6 時間の授業 実践を試み，夕イム，生理的反応，アンケート調 査によってその効果を比較検討した．その結果， 3つの指導法はそれぞれ異なった特質を備えてお り，単一の方法で持久走を行うのではなく，それ ぞれの特質を理解し，それを生かす指導が必要で あると報告している，また，土肥ほか（2004）は， 小学校 6 年生を対象に 5 時間の体育授業で, 助走, 踏切および着地の練習を通して走り幅跳びの練習 効果を捉えるとともに，児童の意識の変容や，そ の意識が運動技能に与える影響を検討した。その 結果，男女とも跳躍距離を伸ばしたが，その原因 が，(1)最適な助走距離を理解したこと，(2)踏み込 み速度や踏切前の速度が増加したこと，(3)得意な 踏切足を理解したことであったと総括している。 これに対し加藤ほか（2000）は，小学校6年生の 体育授業における疾走能力の練習効果について分 析している．6時間の授業でスタートダッシュや 中間疾走を中心に単元計画を立て, 疾走能力の練 習効果を確かめたところ, 疾走能力が向上し，そ の主たる原因がスタートダッシュによる加速局面
とゴール付近での速度持続局面のピッチやストラ イドの改善であったと報告している.

球技の授業研究はこれまでまったく発表されて こなかったが, 最近1篇報告された. Yoshinaga et al. (2003) は, 戦術学習の視点からフラック フットボール教材の有効性を明らかにするため に，学習者の作戦づくりとゲームでの実行過程を 分析し，(1)基本戦術を取り入れた多くの作戦が立 案され，単元進行に伴い守備を想定した作戦へと 発展していくこと，(2)ゲームにおける作戦実行率 が単元進行に伴い増加していくことを明らかにし ている.

\section{4. 指導法に関する研究}

佐藤（1976）は，(1)運動の分節性の知覚理論, (2)運動の転換性の知覚理論, (3)運動単位の知覚理 論, (4)運動類型の知覚理論, (5)運動結合の知覚理 論，(6運動の結合性の知覚理論を中核とした運動 構成理論にもとづく教授学習法の効果を実験的に 研究している。その結果, 運動構成学習は, 学習 者の運動構成能力や発想を助長し, 身体運動観の 変革と運動技術の創造性を触発していくと報告し ている.

梅野ほか（1982）は，一斉学習で進められた学 級とグループ学習で課題解決的に進められた学級 を対象に児童の授業に対する態度を比較検討して いる. その結果, グループ学習学級で高得点が見 られたが，その原因として学習形態を構成してい る「教授活動」が態度形成に大きな役割を果たし たのではないかと推察している.

\section{5. 学級経営と体育授業の関係}

日野ほか（2000）は，学級経営と体育授業との 関係が強いという経験的認識が正しいかどうかを 検証している．学級経営の評価法として「学級集 団意識の調査法」を開発するとともに，この調査 結果と体育授業の診断的・総括的評価との関係に ついて分析した，その結果，単元前，単元後双方 で強い相関を見いだしている。また，体育授業の 評価を高めた児童と授業評価を低下ないし停滞さ せた児童に分けて，学級集団意識を比較したとこ 
ろ，両者に明確な有意差を見いだしている.

\section{III 体育科教育学に関連する基礎的研究}

\section{1. 体育授業研究のための方法開発}

体育授業研究の発展に向けて, 授業分析の方法 開発に大きな関心が向けられてきた。最も大きな 関心が向けられてきたのは，子どもによる体育授 業評価法の開発であった，先駆的な試みは，小林 （1978）によって行われ，その成果は著書「体育 の授業研究」としてまとめられている．梅野ほか （1980）は，小学校低学年用の「体育授業に対す る態度尺度作成」を試み，「よろこび」と「評価」 の 2 次元からなる評価法を開発した，同様に奥村 ほか（1989）は小学校中学年を対象に「態度尺度 作成」を試み， 3 年生では「よろこび」「評価」 の 2 次元， 4 年生では，小林と同様「よろこび」 「評価」「価値」の3次元の評価法を開発した.

一方，高橋ほか（1994）は，体育授業評価は, 体育の目標・内容に対応して作成されるべきだと の立場から小学校の形成的授業評価法の開発に取 り組み, 4 次元（意欲・関心，成果，学び方，協 力） 9 項目の調査票と診断基準を作成している.

また，高橋ほか（1996）は，これまでの授業研 究の成果に検討を加え, 授業観察者が体育授業を 観察評価するための観察チェックリストの開発に 取り組み，「教師の相互作用」「学習環境」「授業 の勢い」「効果的学習」「意欲的学習」の 5 要因で 構成されるリストを開発している。

体育心理学分野からの評価法開発にも目を向け る必要がある，例えば西田（1988）は，学習意欲 検査（AMPET）の標準化を図る研究を行った。 ATPET とは体育授業における学習意欲を動機づ けの観点から，(1)学習ストラテジー，(2)困難の克 服，(3)学習の規範的態度，(4)運動の有能感，(5)学 習の価值，(6)緊張性不安，(7)失敗不安の7つの尺 度から測定する調査法である．西田は，小学生 4 年生から高校生 3 年生まで対象に調查を行い, $\mathrm{AMPET}$ といくつかの外的基準との相関から AMPET が高い弁別能力をもつことを証明してい る.
小林（1998）は，わが国で行われてきた授業分 析を手がかりにその方法論を総説している．授業 分析は教科教育学の基本的な方法であるとの前提 のもとに，これまでわが国で行われてきた授業分 析法に検討を加え，資料価值の高い授業記録の作 り方や授業事象を簡明に記述する手だてとしての カテゴリー分析の意義と方法について考察してい る.

\section{2. 運動嫌いや動機づけの研究}

1970-80 年代の改訂学習指導要領において生 涯体育の基礎を培うための運動の楽しさ体験と運 動に対する好意的態度の形成が強調されるように なった.このことから，動機づけや態度形成をテ 一マとした心理学的研究が盛んに発表されるよう になった。例えば波多野ほか（1981，1982）は， 「体育授業ぎらい」の要因分析を試み，体育嫌い の要因として，(1)能力劣等感（体育授業の中で, 自分自身の持つ能力に対して強い劣等感を感じて いること)，(2運動での楽しさ経験（体育授業の 中で，運動する楽しさや技術向上の喜びを経験す ることができないこと), (3)教師・指導法（体育 教師の性格, 指導理念, 指導法などに対して強い 否定的感情をもつこと）を抽出している.

長谷川ほか（1981）は，中学生を対象にダンス 嫌いに及ぼす要因をボディーイメージを含む自己 概念に関わる運動概念測定質問紙によって検証し ている，その結果，「ダンス嫌い」は運動自体を 嫌うのではなく，自分の容姿やセンスに関心が低 く，体型にも自信がないなどの自己概念や性格に 起因していると報告している。佐々木（1999）は 中学生の体育授業に対する好嫌度と体育授業にお ける生徒の心理的ストレス対処との関係につい て，質問紙法による統計的分析を行っている。そ の結果，体育や運動が嫌いな生徒はごまかしや諦 めなどの回避的コーピングを選択する傾向が強 く，心理的ストレス反応が表出されやすいこと， 一方，体育や運動が好きで，問題を具体的に解決 しようとする生徒は心理的ストレス反応の表出が みられないなどを示した。また佐々木（2003）は， 中学生の体育授業における適応状態の類型化を質 
問紙法によって試み，連帯一適応型，仲間遊び一 不適応型, 脱連帯一不適応型, マイペース一適応 型の 4 つのタイ゚を見だすとともに，それぞれの 心理的特徴を明らかにした。伊藤（1985）は，体 育・スポーツにおける「運動嫌い」のメカニズム について, 動機づけの帰属理論から検証した。こ の研究では, 中学 2 年生, 高校 2 年生, 大学 2 年 生を対象に，運動場面における原因帰属様式を測 定する質問紙を実施し，男女差やスポーツ経験， スポーツに対する好意的態度によって，原因帰属 事態 (成功・失敗) で異なる原因帰属パターン （能力, 努力, 課題の困難度, 相手, 運など）を とることを明らかにした．また，これらの結果か ら，スポーツを継続的に実施したり，非好意的態 度を形成しないためには, 自己の能力に対する自 信と努力によって結果が統制できるという認知が 重要であるとしている．また，伊藤ほか（1987） は体育授業の学習における「楽しさ」を規定する 要因と教師の認識に関する質問紙研究を実施して いる．楽しさを規定する要因は，内発的動機づけ (挑戦, 知的好奇心, 達成), 社会的側面を重視し た内発的動機づけ（仲間との交流，仲間からの承 認), 功利的動機づけ（美容や健康）から想定さ れた質問項目によって測定された。調査の結果, 児童・生徒と教師とでは楽しさの要因のとらえ方 に相違があること，また，児童・生徒の楽しさを 規定する要因として，特に自己の努力によって達 成できるという「統制感」が大きな影響を与える と報告している。

その後も動機づけ研究は，さまざまな理論的枠 組のもとで行われている．細田ほか（1999）は動 機づけの達成目標理論から中学生の体育授業にお ける動機づけについて検討している.伊藤（2001） は多次元モデルの学習動機（目標）を想定して小 学生の体育授業における学習動機の類型化と学習 方略との関係について質問紙法によって検討し， 特に適性処遇の提言を行っている.

\section{3. 体育授業における運動学習研究}

体育科教育における中核的な目標・内容である 運動技能学習に関わるいくつかの基礎的研究がみ
られる，例えば田中（1990）は, Adamsの閉回 路理論とSchmidtのスキーマ理論に共通して運 動技能の習得に重要とされる運動表象（運動に関 わる内的イメージ)に着目した実験研究を実施し， 運動の習熟別で運動を「見ているイメージ」であ る視覚的表象が一定であったのに対して，運動を 「遂行しているイメージ」である運動的表象が運 動習熟に伴って増加すること，また表象の精緻化 はいずれの発達段階にも等しくみられるが, 同一 の運動習熟の段階を比較すると発達差がみられる ことを報告している.

\section{IV 体育科教育学研究の課題}

以上の研究成果をふまえて現状の問題点とそれ に関連した研究課題を指摘したい。第1のカリキ エラム研究や学習指導方法論（授業づくり研究） についていえば，戦後学習指導要領を中心とする カリキュラム論に対応して民間体育団体や研究者 の間で激しい論議が展開されてきたにもかかわら ず，体育学研究の場ではまったくといってよいほ ど論議されてこなかった。商業誌や著書を通して カリキュラム論や学習指導方法論は一方的に主張 したり, 批判されてきたが, 学会の場で論理的に, また実践的デー夕に基づいて論議する必要があ る。そうでなければ, 体育科教育学の知識は一般 化されないし発展も望めない。また，国のカリキ ユラム政策に対して学問的に貢献することもでき ない。

第 2 に，体育授業研究についていえば，この 20 年間に次第に研究量が増えてきたものの，いまだ 氷山の一角を崩し取ったレベルにある，教師行動 や学習行動については，国際的に多くの研究成果 が発表されてきたが, 総じて組織的観察法による 量的研究を通して, 効果的な教師行動や求められ る学習行動の全体的傾向がおぼろげに見えてきた 段階に過ぎない。くわえて，国際的には授業の質 的研究の重要性が指摘されているが，わが国にお いてはいまだ納得のいく研究成果は発表されてい ない，組織的な観察法にくわえて，主観的な記述 法など複数のデータを照合させながら分析するト 
ライアンギュレーション法, 効果的な指導方略を 仮説的に設定し，介入実験単元（授業）を通して 検証する方法など，多様な方法によって実践的研 究を累積させていく必要があろう。授業研究はま さに臨床的研究が重要であり，臨床例の集積によ って，授業の法則が見いだされるはずである。そ のような意味で，体育科教育学研究における「実 践研究」の価值が大きく評価されなければならな い.また，現在のところ，授業研究の対象として は，協力が得られやすいこともあって小学校が多 いが，今後は中学や高校生を対象とした授業研究 を積極的に行っていく必要がある．同様に，対象 となる運動種目についても，いまだ偏りがあり， すべての運動領域にわたって授業分析が行われる 必要がある.

第 3 に，基礎的研究に関しては，他の専門分科 会に投稿された数多くの論文が累積されているは ずである．体育学研究全体に目を配りながら，改 めてその成果を整理することが必要になろう．体 育科教育学の分野では, 基礎的な研究として, 子 どもによる授業評価（態度尺度）の研究に大きな 関心が向けられてきたが，授業の観察法や授業分 析法についても一層大きな努力が払われるべきで あろう．体育授業中の行動ははっきり外に現れる ため, 教室での「頭の中の学習」以上に多彩な観 察が可能であるはずである，その意味では，他教 科以上に，授業研究が発展する可能性をもってい る.そのためにも研究方法 (用具) の開発が重要 である。

体育科教育学研究に関わる学問論 (科学論) の 研究に関心が向けられなければならない．国際的 なスポーツ教育学 (体育教育学) と連動して, ま た教育学という親科学との関連を密にしてその基 本的性格, 研究内容, 研究方法を明らかにしてい く必要がある，最後に，学問のグローバリゼーシ ヨンが急速に進展しているが，残念ながらわが国 の研究は世界的水準で見たとき後れを取っている といわざるを得ない，しかし，わが国の学校体育 実践は世界の最高水準にあることも明らかな事実 であり,経験的な授業論も数多く蓄積されている. 重要なことは，それらの実践的財産を科学的知識
として，また論理的体系として世界に発信するこ とである。

\section{文献}

朝岡正雄（1994）教科体育における運動学習の存在 根拠に関する運動学的一考察. 体育学研究, 39 ： $267-275$.

土肥照典 - 加藤謙一・秋本寛次 (2004) 小学校 6 年生 の体育授業における走り幅跳びの練習効果．体育 学研究, $49: 457-469$.

深見英一郎・高橋健夫 ·日野克博・吉野 聡 (1997) 体育授業における有効なフィードバック行動に関 する検討：特に，子どもの受けとめかたや授業評 価との関係を中心に. 体育学研究, $42 ： 167-179$. 深見英一郎・高橋健夫・細越淳二・吉野 聡 $(2000)$ 体育の単元過程にみる各授業場面の推移パターン の検討一小学校跳び箱運動の授業分析を通して一. 体育学研究, $45 ： 489-502$.

原田貞雄 - 荒木 勉 - 辻野 昭 (1986) 主観的運動 強度を指標としての体育授業設定の試み。体育学 研究, $31: 273-284$.

福ヶ迫善彦・スロト・小松崎敏・米村耕平 - 高橋健 夫（2003）体育授業における「授業の勢い」に関 する検討：小学校体育授業における学習従事と形 成的授業評価との関係を中心に。体育学研究, $48: 281-297$.

波多野義郎・中村精男（1981）「運動ぎらい」の生成 機序に関する事例研究. 体育学研究, $26 ： 177-$ 187.

日野克博 - 高橋健夫 - 八代 勉 - 吉野 聡 - 藤井喜 一（2000）小学校における子どもの体育授業評価 と学級集団意識との関係. 体育学研究, $45 ： 559-$ 610.

堀健太郎・黒川隆志（2003）高校体育授業における 持久走の指導法に関する研究. 体育学研究, 48 ： 667-677.

細田朋美・杉原 隆（1999）体育の授業における特 性としての目標志向性と有能さの認知が動機づけ に及ほす影響. 体育学研究, 44：90-99.

井谷惠子（1993）アメリカにおける体育の概念学習 の発展に関する検討：Basic stuff seriesを中心に. 体育学研究, $38 ： 201-213$.

井谷惠子（2001）アメリカの学校体育におけるフィ 
ットネスプログラムの変容 : 体力づくりからフィ

ットネス教育へ。体育学研究, 46：323-336.

伊藤美智子 - 林 信恵 (2002) 教師行動と生徒によ る授業評価から見たダンス授業の検討．体育学研 究, $47: 333-346$.

伊藤豊彦（1985） スポーツにおける原因帰属様式の 因子構造とその特質. 体育学研究，30：153-160. 伊藤豊彦・織奥信男（1987）体育学習における児 童・生徒の楽しさを規定する要因と教師の認識. 体育学研究, $33: 123-133$.

伊藤豊彦（2001）小学生における体育の学習動機に 関する研究：学習方略との関連および類型化の試 み. 体育学研究, $46: 365-379$.

伊藤精男・波多野義郎（1982）「体育授業ぎらい」の 生起に関する研究. 体育学研究, $27 ： 239-246$.

加藤謙一 - 関戸康雄 - 岡崎秀充 (2000) 小学校 6 年生 の体育授業における疾走能力の練習効果. 体育学 研究，45：530-542.

小林 篤（1978）体育の授業研究. 大修館書店：東 京.

小林 篤（1998）体育授業分析方法論. 体育学研究, $43: 71-78$.

近藤智靖・岡出美則（1997）身体の経験としてのス ポーツ授業の中で保証しようとした経験の内容： ドイツの試みにみる日本の教科教授モデルへの示 唆. 体育学研究, $41 ： 369-379$.

前川峯雄（1974）体育教育学の確立を目ざして．体 育学研究, $18: 155-161$.

中村敏雄（2003）体育は何を教える教科か. 体育学 研究, $48 ： 655-665$.

成田十次郎編著（1987）体育科教育学。ミネルヴァ 書房：京都.

西田保（1988）体育における学習意欲検査 （AMPET）の標準化に関する研究一達成動機づけ 論的アプローチ一. 体育学研究, $34: 45-62$.

尾縣 貢 - 高橋健夫 - 高本恵美 - 細越淳二 ・ 関岡康

雄（2001）オーバーハンドスロー能力改善のため の学習プログラムの作成：小学校 $2 \cdot 3$ 年生を対象 として. 体育学研究, 46:281-294.

岡出美則 (1983) Ommo Grupeの「身体性の理論」 の体育教授学的意義について，体育の科学，28： 90-100.

岡出美則（1997）ドイツにおける「スポーツの中の 行為能力」論形成過程にみるスポーツの意味をめ
ぐる論議. 体育学研究, 42：1-18.

岡出美則（2001）体育科教育学のオーバービュー. 杉本厚夫編 体育教育を学ぶ人のために，世界思 想社：京都, pp. 300-324.

奥村基治・梅野圭史 - 辻野 昭（1989）体育科の授 業に対する態度尺度作成の試み一小学校中学年児 童を対象にして一。体育学研究, $33 ： 139-148$.

里見悦郎（1992）ソビエト社会主義共和国連邦の学 校体育改革をめぐる諸問題について。体育学研究, 37 : 183-194.

鈴木秀人・永島惊正（2000）英国におけるナショナ ル・カリキュラム (体育) が学校体育カリキュラ ムの実際に及ほしている影響に関する検討：通学 制私立中学校の事例研究. 体育学研究, 45：632649 .

Siedentop, D. (1983) Research on Teaching Physical Education. In: Tenplin, T.J., and Olson, J.K. (Eds) Teaching in Physical Education. Human Kinetics: Champaign, pp. 3-15.

金 善慶・松浦義行（1988）幼児及び児童における 基礎運動技能の量的変化と質的変化に関する研究. 体育学研究, 33 : 27-38.

草深直臣（1996）体育・スポーツの戦後改革に関す る「第一次米国教育使節団報告書」の作成過程. 体育学研究, 41：59-67.

佐々木万丈（1999）体育学習に打ける能力的不適応 経験時のコーピングと心理的ストレス反応の関 係：中学生の場合. 体育学研究, 44:445-456.

佐々木万丈 (2002) 中学生用体育学習心理的ストレ スレベル測定尺度の短縮版の開発と標準化. 体育 学研究, $47: 383-394$.

佐々木万丈（2003）体育の授業に対する適応：中学 生の場合. 体育学研究, 48：153-167.

佐々木万丈（2004）中学生の体育授業における社会 的スキルの分析：性，学年，体育授業への適応感 に着目して。体育学研究, 49：423-434.

佐藤 裕（1976）運動構成学習の理論と方法に関す る研究一体操的運動における生徒の自発的構成活 動をねらった教授法の理論と実践的手続き一。体 育学研究, $21: 125-135$.

佐藤 裕・西村清巳（1978）教育実習生の授業技術 の変容過程と指導観の変容様態についての研究. 体育学研究, $23 ： 121-128$.

高橋健夫（1987）体育科教育法の現状と体育科教育 
学の課題. 成田十次郎編著 体育科教育学. ミネ ルヴァ書房：京都, pp. 57-63.

高橋健夫・岡沢祥訓・中井隆司（1989）教師の「相 互作用」行動が児童の学習行動及び授業成果に及 ぼす影響について．体育学研究，34：191-200.

高橋健夫・岡沢祥訓・大友 智 (1989) 体育の ALT 観察法の有効性に関する検討一小学校の体育授業 分析を通して一。体育学研究, $34: 31-43$.

高橋健夫 - 岡沢祥訓 - 中井隆司 - 芳本 真 (1991) 体育授業における教師行動に関する研究一教師行 動の構造と児童の授業評価との関係一。体育学研 究, $36: 193-208$.

高橋健夫 ·長谷川悦示 ·刈谷三郎 (1994) 体育授業 の「形成的授業評価法」作成の試み：子どもの授 業評価の構造に着目して。体育学研究, $39 ： 29$ 37.

高橋健夫 - 長谷川悦示・日野克博 - 浦井孝夫 (1996) 体育授業観察チェックリスト作成の試み：観察者 の評価観点の構造を手がかりに。体育学研究, $41: 181-191$.

高橋健夫（2000）子どもが評価する体育授業過程の 特徵：授業過程の学習者行動及び指導行動と子ど もによる授業評価との関係を中心にして，体育学 研究, 45：147-162.

竹田清彦・大久保英哲（1985）西ドイッにおける “Sportgymnasium 学校実験”に関する研究一構想 の出現背景と概要一. 体育学研究, $30: 1-21$.

高本恵美 - 出井雄二 - 尾縣 貢 (2004) 児童の投運 動学習効果に影響を及ほす要因. 体育学研究, $49: 321-333$.

竹田清彦ほか（1997）体育科教育学の探究. 大修館 書店 : 東京.

田中雅人（1990）運動習熟に伴う表象の変容とその
発達差. 体育学研究, 34:293-303.

上原禎弘・梅野圭史（2000）小学校体育授業におけ る教師の言語的相互作用に関する研究：走り幅跳 びの授業における品詞分析の結果を手がかりとし て. 体育学研究, $45: 24-38$.

上原禎弘・梅野圭史（2003）小学校体育授業におけ る教師の言語的相互作用の適切性に関する研究： 学習成果（技能）を中心としてとして，体育学研 究, $48: 1-14$.

梅野圭史・辻野 昭（1980）体育科の授業に対する 態度尺度作成の試み一小学校低学年児童について 一. 体育学研究, $25 ： 139-148$.

梅野圭史・辻野 昭（1982）体育科における学習形 態と児童の授業に対する態度との関係一小学校低 学年を中心として一. 体育学研究, $27: 1-15$.

米村耕平・福ヶ迫喜彦・高橋健夫 (2004) 小学校体 育授業における「授業の雾团気」と形成的授業評 価との関係についての検討. 体育学研究, 49 ： 231-243.

Yonemura, K., Fukugasako, Y., Yoshinaga, T., and Takahashi, T. (2004) Effects of Momentum and Climate in Physical Education Class on Students' Formative Evaluation. International Journal of Sport and Health Science, 2: 25-33.

Yoshinaga, T., Takahashi, T., and Onizawa, Y. (2003) A Study on the Effectiveness of Flag Football as Teaching Materials in Physical Education Classes: Through Analysis of the Change in Planning and Executing Strategies by Children. International Journal of Sport and Health Science, 1: 171-177. $\left(\begin{array}{l}\text { 平成 } 17 \text { 年 } 2 \text { 月 } 15 \text { 日受付 } \\ \text { 平成 } 17 \text { 年 } 2 \text { 月 } 19 \text { 日受理 }\end{array}\right)$ 